\title{
A new Eimeria (Apicomplexa: Eimeriidae), possessing mitra- shaped oocysts, from the Neotropical chelid turtle Batrachemys heliostemma (Testudines: Chelidae), and its comparison with Eimeria mitraria (Laveran \& Mesnil 1902)
}

\author{
Pavel Široký/ ${ }^{+}$, Martin Kamler*, D avid Modrý*/** \\ Department of Biology and Wildlife Diseases *Department of Parasitology, University of Veterinary and Pharmaceutical \\ Sciences, Palackého 1-3, CZ-612 42 Brno, Czech Republic **Institute of Parasitology, Biological Center, Academy of Sciences of \\ the Czech Republic, Èeské Budì jovice, Czech Republic \\ Eimeria jirkamoraveci $s p$. $n$. is described from faeces of two specimens of the toad-headed, side-necked turtle \\ Batrachemys heliostemma collected at Iquitos in Peru. Oocysts are ovoid to almost spherical, 10.6 (8-12) $\times 8.9$ \\ (7-10) $\mu \mathrm{m}$, without micropyle, polar granule and oocyst residuum. One conically stretched end and three blunt \\ conical tubercles at the opposite end of oocyst give it mitra-like appearance. Sporocysts are elongated, ellipsoidal, \\ $7.2(6-8) \times 4.1$ (4-4.5) $\mu m$, with a small, knob-like Stieda body and sporocyst residuum composed of fine granules. \\ To avoid possible conspecificity, the described new species is thoroughly compared with the most similar coccidium, \\ E. mitraria, collected from its type host, Chinemys reevesii.
}

Key words: Coccidia - Apicomplexa - Eimeria jirkamoraveci sp. n. - turtles - Batrachemys - Peru

Batrachemys heliostemma McCord, Joseph-Ouni \& Lamar, 2001 is a Neotropical chelid turtle described recently from the upper Amazon basin, with distribution ranging from Southern Venezuela, Western Brazil, to Peru, Ecuador, and Southeastern Colombia. It seems, that this species prefer high, non-flooded forests near permanent water bodies, and shallow and clear waters rather than the turbid, deeper waters of saturated lowlands. Little is known about other aspects of its ecology (McCord et al. 2001). Generic affiliation of this turtle has been questioned and it is even not solved definitely (Bour \& Zaher 2005).

With more than sixty species, South America represents an area of rich turtle diversity. Up to recently, only eight species of Eimeria were described and named from turtles of this region, three of them (E. jaboti Carini 1942, E. lainsoni Hùrková, Modrý, Koudela \& Šlapeta 2000, and E. motelo Hùrková, Modrý, Koudela \& Šlapeta 2000) parasitize the Yellow-footed tortoise Geochelone denticulata (Linnaeus 1766). Three others (E. lagunculata Lainson, Costa \& Shaw 1990, E. mammiformis Lainson, Costa \& Shaw 1990, and E. podocnemis Lainson, Costa \& Shaw 1990) were described from the Arrau turtle Podocnemis expansa (Schweigger 1812) and one species was described from each of the Galápagos tortoise Geochelone nigra (Quoy \& Gaimard 1824) and the Bigheaded turtle Peltocephalus dumerilianus (Schweigger 1812) (Carini 1942, Lainson et al. 1990, Couch et al. 1996, Lainson \& Naiff 1998, Hùrková et al. 2000).

Financial support: D Modrý and M Kamler received grants GA CR 524/03/D104 and 524/03/H133, respectively

+Corresponding author: sirokyp@vfu.cz

Received 9 February 2006

Accepted 3 May 2006
We had an opportunity to examine the faeces of two specimens of Batrachemys heliostemma collected at Iquitos and found a new Eimeria possessing mitra-shaped oocysts, described and named in this paper. To avoid possible conspecificity with E. mitraria (Laveran \& Mesnil 1902), a species reported from more than a dozen turtles from three continents (McAllister \& Upton 1989, Lainson \& Naiff 1998, Segade et al. 2004), we re-isolated this coccidium from its type host, the Chinese three-keeled pond turtle Chinemys reevesii (Gray 1831) and have made a thorough comparison.

\section{MATERIALS AND METHODS}

Two sub-adult females of $B$. heliostemma were collected in March 2002 at Anquilla village at Rio Nanay, 50 $\mathrm{km}$ west of Iquitos, Peru. They were imported alive to the Czech Republic in April 2002, placed together in one plastic box, where faecal samples were collected. Freshly obtained faeces were placed in $2.5 \%$ aqueous $(\mathrm{w} / \mathrm{v})$ potassium dichromate $\left(\mathrm{K}_{2} \mathrm{Cr}_{2} \mathrm{O}_{7}\right)$ solution, mixed thoroughly, and the oocysts allowed to sporulate in shallow plastic containers at $20-23^{\circ} \mathrm{C}$. The material was then stored at $4^{\circ} \mathrm{C}$ until its examination. Samples were microscopically examined after concentration by flotation with modified Sheather's sugar solution (specific gravity 1.3). Since oocysts became quickly deformed (after circa $15 \mathrm{~min}$ ), centrifuged sediment of further samples was used without concentration by sugar solution. Oocysts were measured and photographed using an Olympus Provis AX 70 microscope equipped with Nomarski interference contrast optics (NIC). Morphological features are described according to Duszynski and Wilber (1997). Measurements were made of 30 oocysts, using a calibrated ocular micrometer and are given in micrometers $(\mu \mathrm{m})$ as means, followed by ranges in parentheses. For a comparison, material with oocysts of E. mitraria was obtained from a female $C$. reevesii originating from Japan. This turtle was 
collected in October 2003 close to Fukuoka, Kyushu island, imported into the Czech Republic by a private breeder, then housed, sampled and examined the same way.

\section{RESULTS}

Coprological examination of two B. heliostemma revealed presence of mitra-shaped oocysts of a previously undescribed eimerian coccidium. The new species is described and named as follows. The original description of E. mitraria, the species possessing most similar oocysts, contains insufficient data on its morphology necessitating a re-description of the oocyst of E. mitraria.

\section{Eimeria jirkamoraveci $\mathrm{sp} . \mathrm{n}$.}

(Figs 1-3, 5)

Description - Oocysts are ovoid, sub-spherical to almost spherical, $10.6(8-12) \times 8.9(7-10)$, oocyst shape index (SI, length/width) 1.2 (1-1.5); micropyle, polar granule and oocyst residuum absent. Oocyst wall smooth, colorless, under light microscopy single-layered, $\sim 0.5$ thick. One end of oocyst is conically stretched, whereas opposite end bears three blunt conical tubercles, giving the oocyst its mitra-like appearance. Sporocysts are elongated, ellipsoidal, $7.2(6-8) \times 4.1(4-4.5)$, with a smooth, thin and colorless sporocyst wall and a sporocyst SI of 1.75 (1.5-2). Stieda body present, small, knob-like, 0.5-1 high and $\sim 1-1.5$ wide $(n=8)$, substieda body is not discernible. Sporocyst residuum consists of fine granules, that are either organized in a compact sphere $\sim 2-4 \times 2-3(n=10)$ or scattered among sporozoites. Sporozoites are elongated, arranged head to tail within the sporocyst. Each sporozoite bears a spherical to sub-spherical refractile body $(\sim 1.5-2 \times 2-2.5 ; n=8)$, nucleus is not discernible.

Type-host - Northern toad-headed side-necked turtle Batrachemys heliostemma McCord, Joseph-Ouni \& Lamar, 2001 (Reptilia: Testudines: Chelidae).

Type-locality - Anquilla village, Iquitos, Departamento
Loreto, Peru (0354’45" S, 073³9’39" W).

Prevalence - Not studied, we examined a mixed faecal sample originating from both specimens.

Sporulation time - Not recorded.

Site of infection - Unknown, oocysts were acquired from faeces of living turtles.

Type-material - Photosyntypes are deposited in the Department of Parasitology, University of Veterinary and Pharmaceutical Sciences Brno, Czech Republic under no. R 167/02.

Etymology - Specific epithet "jirkamoraveci" is given in honour of our friend, Dr Jiøi Moravec, who has contributed considerably to the knowledge of the biodiversity of the western Amazon basin.

\section{Eimeria mitraria (Laveran \& Mesnil 1902)} (Fig. 4)

Re-description - Oocysts ovoid $14.4(13-16) \times 10.4(9-13)$, oocyst SI 1.4 (1.23-1.58), without micropyle, polar granule and oocyst residuum. Oocyst wall smooth, colorless and, under light microscopy, single-layered, $~ 0.5$ thick. One end of oocyst bears one conical projection 1-1.5 long, whereas opposite end bears three similar projections, giving the oocyst mitra-like or projectile-like appearance. Sporocysts ellipsoidal, 7.1 (6-7.5) $\times 4.4$ (4-5), with smooth and colorless sporocyst wall and a sporocyst SI of 1.63 (1.33-1.88). Stieda body is present, tiny, knob-like, $\sim 0.5$ $0.1(n=7)$, substieda body is not discernible. Sporozoites elongate, arranged head to tail within sporocyst. Each sporozoite bears a prominent sub-spherical refractile body $1.5-2 \times 2-3(n=9)$ at one end, nucleus is not discernible. Sporocyst residuum is a compact granular mass $\sim 2-4$ in diameter, or is scattered among sporozoites.

\section{DISCUSSION}

Eimerian parasites are traditionally considered to be strictly host specific and geographic origin and host sys-

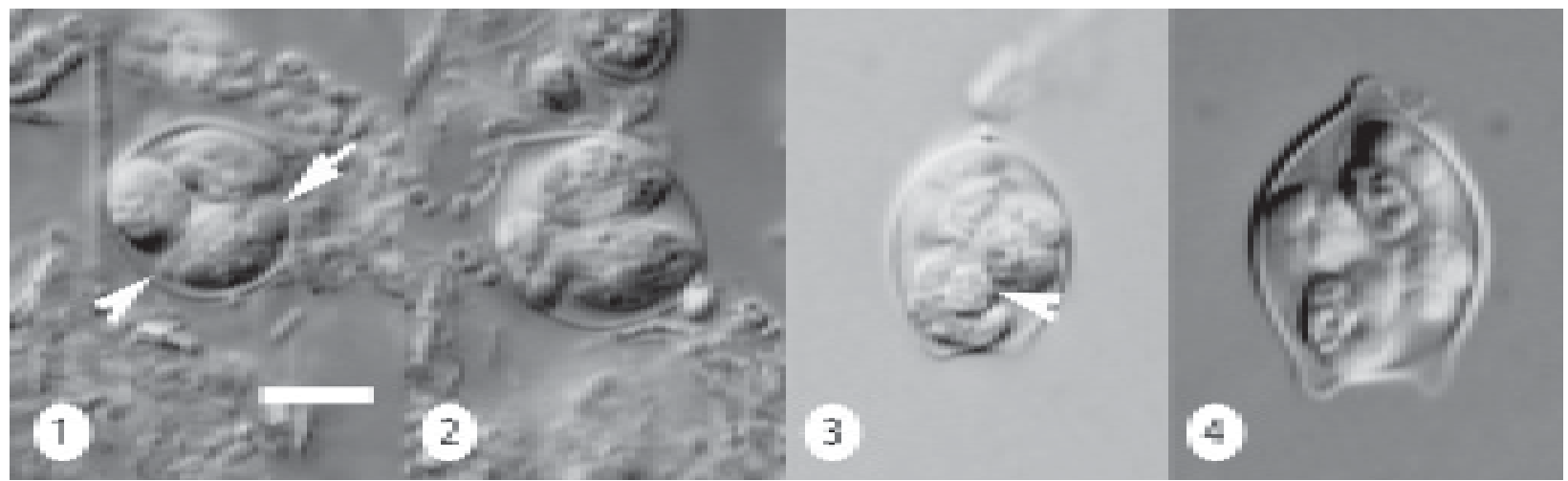

Nomarski interference contrast photographs of oocysts, all in the same scale. Fig. 1: sporulated oocyst of Eimeria jirkamoraveci sp. n.; note distinct Stieda body (arrowhead) and refractile body (arrow). Bar $=5 \mu \mathrm{m}$. Figs 2-3: overall shape of sporulated oocysts of $E$. jirkamoraveci sp. n. with distinct conical tubercles; note granular sporocyst residuum (arrowhead). Fig. 4: sporulated oocyst of E. mitraria (Laveran \& Mesnil 1902); note the different size, shape and more pronounced conical projections of the oocyst wall, compared to $E$. jirkamoraveci $\mathrm{sp}$. $\mathrm{n}$. 


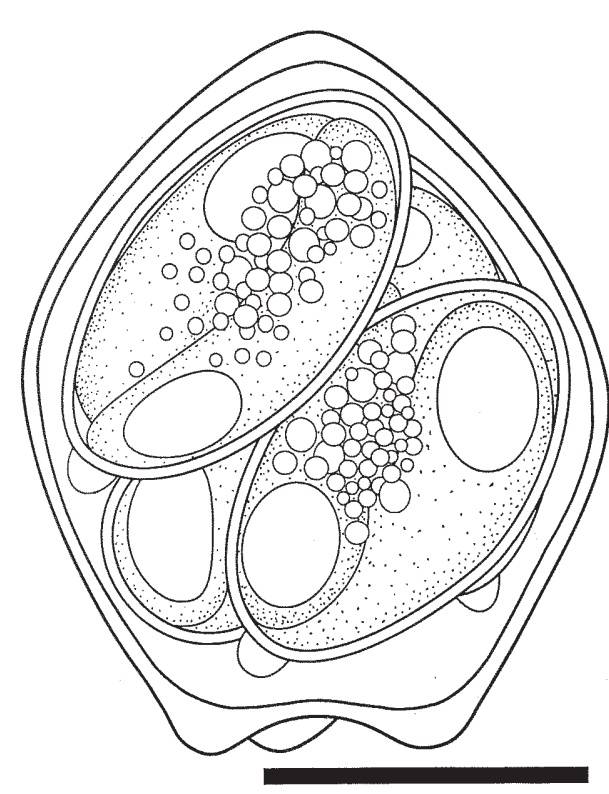

Fig. 5: composite line drawing of sporulated oocyst of Eimeria jirkamoraveci $\mathrm{sp} . \mathrm{n}$. Bar $=5 \mu \mathrm{m}$.

tematics are common tools in their taxonomy (Duszynski 1986). Nevertheless the relevance of this trait for reptilian Eimeria species has been repeatedly questioned (Wacha \& Christiansen 1974, 1976, McAllister \& Upton 1989). This is why we are including all chelonian Eimeria from Neotropical zoogeographical region in our differential diagnosis. Moreover, both known Eimeria spp. possessing mitra-shaped oocysts are considered.

Among all Eimeria spp. parasitizing side-necked turtles of suborder Pleurodira (families Pelomedusidae and Chelidae sensu Gaffney \& Meylan 1988) none is similar to E. jirkamoraveci $\mathrm{sp}$. n., including recently discovered Eimeria from the African side-necked turtle Pelomedusa subrufa (Lacépède 1788) (Široký et al. 2006). Also none of the five remaining species of genus Eimeria previously described from turtles of the Neotropical region, resembles the new species descried above (Carini 1942, Lainson 1968, Lainson et al. 1990, Couch et al. 1996, Lainson \& Naiff 1998, Hùrková et al. 2000).

Consequently, only two Eimeria with mitra-like oocysts resemble E. jirkamoraveci sp. n. - E. mitraria (Laveran \& Mesnil 1902) described from the Chinese threekeeled pond turtle Chinemys reevesii (Gray 1831) and $E$. stylosa McAllister \& Upton 1989, a parasite of the redeared slider turtle Trachemys scripta elegans (WiedNeuwied 1838). Oocysts of E. stylosa are definitely larger and have much longer and sharper projections (McAllister \& Upton 1989).

E. mitraria is the most similar coccidium to E. jirkamoraveci sp. n., hence we give particular attention to their comparison. In the original description, Laveran and Mesnil (1902) reported oocysts of E. mitraria to be $15 \times$ $10 \mu \mathrm{m}$. These data fit well the range of oocysts we obtained from $C$. reevesii. In contrast, E. jirkamoraveci sp. n. has smaller, more spherical oocysts with less pronounced conical projections of oocyst wall.

McAllister et al. (1990) suggested that most species of coccidia in Testudines are host-specific at family level, although without any experimental or molecular data. $B$. heliostemma is a chelid turtle only very distantly related to geoemydid turtle $C$. reevesii. Separated evolutionary lineages of turtles of the suborders Pleurodira (families Chelidae and Pelomedusidae) and Cryptodira (all other turtle families) have been independently evolving for almost 200 millions of years (Gaffney et al. 1987). Additionally, there is also a long-term separation of Neotropical and Oriental zoogeographical regions (Smith et al. 2004). Based on the above-mentioned morphological differences, geographic isolation, and phylogenetic distance of $B$. heliostemma to any other turtle species known to be parasitized by Eimeria with mitra-shaped oocysts, we consider E. jirkamoraveci to be a new species.

\section{ACKNOWLEDGEMENTS}

To Petr Petrás for providing us with the female Chinemys reevesii. Jiøi Moravec (National Museum, Prague) in cooperation with the Museo de Zoologia - Unap, Iquitos (research 452-2000-Inrena-Loreto) and Universidad de la Amazonía Peruana, Iquitos collected both specimens of B. heliostemma.

\section{REFERENCES}

Bour R, Zaher H 2005. A new species of Mesoclemmys, from the open formations of northeastern Brazil (Chelonii, Chelidae). Pap Avuls Zool 45: 295-311.

Carini A 1942. Sobre uma Eimeria da "Testudo tabulata". Arq Biol (São Paulo) 26: 163-164.

Couch L, Stone PA, Duszynski DW, Snell HL, Snell HM 1996. A survey of the coccidian parasites of reptiles from islands of the Galápagos archipelago: 1990-1994. J Parasitol 82: 432-437.

Duszynski DW 1986. Host specificity in the coccidia of small mammals: Fact or fiction? In M Berecky, Advances in Protozoological Research, Vol. 33, Symposia Biologica Hungarica, Akadémiai Kiadó, Budapest, p. 325-337.

Duszynski DW, Wilber PG 1997. A guideline for the preparation of species descriptions in the Eimeriidae. J Parasitol 88: 333-336.

Gaffney ES, Meylan PA 1988. A phylogeny of turtles. In MJ Benton, The Phylogeny and Classification of the Tetrapods, Vol. 1: Amphibians, Reptiles, Birds, Clarendon Press, Oxford, p. 157-219.

Gaffney ES, Hutchinson JH, Jenkins FA, Meeker LJ 1987. Modern turtle origins: The oldest known cryptodire. Science 237: 289-291.

Hùrková L, Modrý D, Koudela B, Šlapeta J 2000. Description of Eimeria motelo sp. n. (Apicomplexa: Eimeriidae) from the Yellow footed tortoise, Geochelone denticulata (Chelonia: Testudinidae), and replacement of Eimeria carinii Lainson, Costa \& Shaw, 1990 by Eimeria lainsoni nom. nov. Mem Inst Oswaldo Cruz 95: 829-832.

Lainson R 1968. Parasitological studies in British Honduras. IV. Some coccidial parasites of reptiles. Ann Trop Med Parasitol 62: 260-266.

Lainson R, Naiff RD 1998. Eimeria peltocephali n. sp., 
(Apicomplexa: Eimeriidae) from the freshwater turtle Peltocephalus dumerilianus (Chelonia: Pelomusidae) and Eimeria molossi n. sp., from the bat, Molossus ater (Mammalia: Chiroptera). Mem Inst Oswaldo Cruz 93: 81-90.

Lainson R, Costa AM, Shaw JJ 1990. Eimeria species (Apicomplexa: Eimeriidae) of Podocnemis expansa (Schweigger) and Geochelone denticulata (Linn.) from Amazonian Brazil (Reptilia: Chelonia). Mem Inst Oswaldo Cruz 85: 383-390.

Laveran A, Mesnil F 1902. Sur quelques protozoaires parasites d'une tortue d'Asie (Damonia reevesii). C R Séances Acad Sci (Ser 3) 135: 609-614.

McAllister CT, Upton SJ 1989. The Coccidia (Apicomplexa: Eimeriidae) of Testudines, with descriptions of three new species. Can J Zool 67: 2459-2467.

McAllister CT, Upton SJ, McCaskill LD 1990. Three new species of Eimeria (Apicomplexa: Eimeriidae) from Apalone spinifera pallidus (Testudines: Trionychidae) in Texas, with a redescription of E. amydae. J Parasitol 76: 481-486.

McCord WP, Joseph-Ouni M, Lamar WW 2001. A taxonomic reevaluation of Phrynops (Testudines: Chelidae) with the description of two new genera and a new species of
Batrachemys. Rev Biol Trop 49: 715-764.

Segade P, Ayres C, Cordero A, Crespo-Gonzáles C, GarcíaEstévez JM, Iglesias R 2004. Intestinal coccidia from the European pond turtle, Emys orbicularis, in Galicia (NW Spain). In S Mas-Coma, MD Bargues, JG Esteban, MA Valero, IX. European Multicolloquium of Parasitology, Valencia, Spain, 18-23 July, programme and abstracts, p. 584.

Široký P, Kamler M, Modrý D 2006. Eimeria lokuma n. sp. (Apicomplexa: Eimeriidae), a new coccidium from African helmeted turtle Pelomedusa subrufa (Lacépède, 1788) (Testudines: Pelomedusidae). Syst Parasitol, in press

Smith AG, Smith DG, Funnell BM 2004. Atlas of Mesozoic and Cenozoic Coastlines, Cambridge University Press, Cambridge, $99 \mathrm{pp}$.

Wacha RS, Christiansen JL 1974. Systematics of the eimerian parasites from North American snakes of the family Colubridae, and their prevalence in the colubrids of Iowa. J Protozool 21: 483-489.

Wacha RS, Christiansen JL 1976. Coccidian parasites from Iowa turtles: systematics and prevalence. J Protozool 23: 57-63. 